\title{
Tourism and Hospitality Training: Hallmark of the Culinary and Hospitality Management Institute
}

\author{
Donna M. Williams \\ Culinary and Hospitality Management Institute ${ }^{1}$
}

\begin{abstract}
This paper traces the evolution of tourism and hospitality training in The Bahamas over the last 40 years, focusing on stakeholders, pioneers, partnerships, organizational structures, programs, and other key factors that have contributed to the establishment and operation of the Culinary and Hospitality Management Institute at the College of The Bahamas.
\end{abstract}

\section{INTRODUCTION}

The Bahamas in the 1960s experienced robust economic growth and tourism was cited as the nation's primary economic activity, highlighting the need for tourism and hospitality training. The country had passed the "magic" million mark in tourist arrivals, and this developmental phenomenon emphasized the need for manpower to service the budding industry. In January 1973 the Bahamas Training Council was formed to address this need (Bahamas Hotel Training College, 1997). An expressed philosophy of the Council was the establishment of a tourism and hospitality training facility to provide comprehensive training in an academic system to facilitate the human resource demands of tourism and hospitality development in the country. This paper captures the essence of tourism and hospitality training in The Bahamas over the last forty years, focusing on stakeholders, pioneers, partnerships, organizational structures, programs, and other key factors.
The Bahamas Hotel Training College (BHTC) was established to fulfill the philosophy of the Bahamas Training Council. The initial programs developed were a diploma program, vocational teacher courses, and a summer school program. These programs were designed to enable The Bahamas, as well as other Caribbean countries, to have access to a specialist facility for tourism and hospitality training. Alongside the formation of the academic programs was a mandate to incorporate an industry training component to assist in preserving professional standards, which was "appropriately named the Industry Training Department" (Blundell, personal communication, 2014). The BHTC model it was designed to meet the demands of a rapidly changing society (Smith \& Glover, 1983).

The Bahamas Training Council formed out of a tripartite agreement of the Bahamas Hotel Association, the Bahamas Hotel and Allied Workers Union and the Government of the Bahamas represented by the Ministry of

\footnotetext{
${ }^{1}$ Donna M. Williams, Assistant Professor, Culinary and Hospitality Management Institute, The College of The Bahamas, P.O. Box N-4912, Nassau, Bahamas.

Acknowledgments: The author is grateful to the students of the College of The Bahamas course TOUR411 held in Spring 2014 who assisted: Ashley Albury, Travis Bowe, Adam Cartwright, Leonard Cumberbatch, Santino Higgs, Adrianna Knowles, Shardae Pratt, Kristie Russell, Olivia Taylor, Alexander Thompson, and Daronique Young. E-mail: donna.williams@cob.edu.bs

APA reference: Williams, D. M. (2014). Tourism and hospitality training: Hallmark of the Culinary and Hospitality Management Institute. The International Journal of Bahamian Studies, 20(2), III 22-27. https://doi.org/10.15362/ijbs.v20i2.239
}

(C) D. M. Williams, 2014. Journal compilation (c)The International Journal of Bahamian Studies, 2014 
Tourism, the Ministry of Labor and the Ministry of Education, to provide hotel training for the country. The Council members were comprised of the chairman of the Council, Charles "Cap" Smith, at that time permanent secretary at the Ministry of Education, Stephen Blundell, Chief Operating Officer of the Bahamas Training Council, and Hugh Sands, a prime mover within the Council (Roker, personal communication, 2014). Other notables included Thomas Bastian, President of the Bahamas Hotel and Allied Workers Union, Michael Reckley of the Bahamas Hotel Employers Association, and the Bahamas Hotel Association member J. Barrie Farrington (Culmer, personal communication, 2014). The Council devised various programs including a hotel diploma, cook apprenticeship program and short courses such as Housekeeping, Front Office, Bartending, and Hotel Accounting. Special programs for lifeguards and other craft courses were offered based on the national need. All programs were operated on a block system (Smith, personal communication, 2014).

According to Blundell, a key factor in the development of the programs was a unique structure. He recalled that, "the purpose of the unusual structure of the training was to be able to offer conditions of employment and salaries in keeping with the hotel industry so that top quality people would be attracted" (Blundell, personal communication, 2014). Hence employees were allowed to attend the College to upgrade on company time. To launch the training college, lecturers from Malta, Singapore and Cambridge, England, along with well-suited Bahamians such as Sherwin Stewart, Berkley Williamson, and Michael Smith were recruited to attend Florida International University to engage in academic upgrades. The vision of Blundell was to Bahamianize the BHTC; consequently all overseas instructors upon hire were made aware that as Bahamian students completed degrees abroad they would be replaced. Blundell's (1973-1978) tenure at the BHTC is highlighted with the many worthy partnerships which he formed for the Bahamas Hotel Training College. The partnership with Florida International University in collaboration with Dr. William Morgan is still remembered in the hearts and minds of many Bahamians who took advantage of study aboard opportunities. (Blundell, personal communication, 2014)

The BHTC Nassau campus was located on College Avenue, Oakes Field. From the early days alumni valued the close-knit relationships they shared with each other and felt an intense loyalty to the school. The school grew as they gained success and made recommendations to others to attend the Bahamas Hotel Training College. The Freeport campus was located on West Settlers Highway and managed by an industry trainer (Dahl-Brown, personal communication, 2014).

Michael Smith (1979-1984) succeeded Stephen Blundell and was the first Bahamian Executive Director of the Bahamas Hotel Training College. Prior to his confirmation as Executive Director, Smith had served as an industry trainer with responsibility for the provision of customized training to meet hotel and allied industry needs. Under the leadership of this visionary, the BHTC attained international college accreditation status through the Southern Association of Colleges and Schools. The BHTC became the first non-United States institution to gain this accreditation. He also formalized the hiring requirements of tutors to include a minimum of a Bachelor's degree in hospitality or related area, or an Associate Degree in Culinary Arts along with industry management experience. $\mathrm{He}$ felt this would increase the school's competitiveness in the world tourism market (Smith, 2014). 
Smith formed several critical partnerships during his term such as: The Commonwealth Fund and Technical Corporation (CFTC) donor of scholarship for Commonwealth students; and the European Economic Community (EEC) general financing and scholarship opportunities for the BHTC. Hence, international students became an integral constituent of the student body. Over the years students from Nigeria, Uganda, Kenya, Ghana, India, Pakistan and many Caribbean countries matriculated through the BHTC. Worldwide, their skill and professionalism upon entrance into the workforce encouraged students from other countries to join the BHTC. These countries included the United States and British Virgin Islands, the Cayman Islands, Zimbabwe, Israel and Turkey, among others (Smith, personal communication, 2014).

The BHTC has maintained its philosophy and its mandate to provide career-oriented education and training. The BHTC to-date has well-developed support systems both in and out of the classroom, allowing students who are serious about their goals to thrive. Many industry giants were tutors during the formative years. Notable Bahamian tutors included Berkley Williamson, Kendal Johnson and Pandora McKinney Smith. John Rosevear, originally from Canada, served the College for 40 years and is known for his impact on the development of hotel bookkeeping and accounting in the country. Lucille Culmer was the first confirmed employee and served as receptionist (Culmer, personal communication, 2014). She was quickly joined by Genevieve Roker as the BHTC secretary having served as Blundell's administrative assistant at the Council (Roker, personal communication, 2014). Table 1 lists the names of other notable instructors:
Table 1

\begin{tabular}{|l|l|}
\hline \multicolumn{1}{|c|}{ Tutor } & \multicolumn{1}{c|}{ Area of Specialty } \\
\hline Chef Norman Webber & Food and Beverage \\
\hline Chef Kevin Robson & Pastry and Baking \\
\hline Charles Illvento & Hotel Studies \\
\hline Jeffrey Wartell & Hotel Studies \\
\hline Hans Von Rotz & Pastry \& Baking \\
\hline Peter Martini & Culinary Arts \\
\hline Berkley Williamson & Beverage Studies \\
\hline Rocko Angelo & Math and Bookkeeping \\
\hline
\end{tabular}

The doors opened to students in 1974 with 13 students participating in the Hotel Tourism and Catering program. It was the first school in the region devoted to the field of hotel management. The groundbreakers in the first degree program included Berkley Pilgram, Michael Siehen, Joreen Brown, Jeanna Grey, Hensley and Etta Culmer along with the "Crazy 7": Kendall Johnson, Brendan Foulkes, Linda Hall, Andrew Barnett, Elston Dean and Colin Knowles. Kendall Johnson indicated that the two-year program was intense, with 96 credits required for completion and students attending classes five days per week. Most of these students hold influential positions in the industry today (K. Johnson, personal communication, 2014). Many short courses were offered with much interest from hotel workers. The Apprentice-Cook Program commenced in 1976 with 24 students (K. Johnson, personal communication, 2014). The expansion of the Apprentice-Cook Certification was led by Berkley. J. Smith who became the coordinator of the program at the governmental level (Roker, personal communication, 2014). Edwin Johnson and Bernard Dawkins were recruited upon completion of their culinary training aboard as Chef Instructors (Culmer, personal communication, 2014).

Other Executive Directors making 
contributions to the development of the BHTC included Lincoln Marshall (1984-1986), Michael Pinchbeck (1987-1990), and Iva Dahl-Brown (1990-1999). Dahl-Brown was promoted from industry trainer in Freeport to Executive Director. She served the longest term as Executive Director in the history of the College. Dahl-Brown engaged in aggressive curriculum review, aligning programs with United States colleges, moving from the British system of diplomas to offering associate degrees. She continued to form significant partnerships as did her predecessors. Under her leadership the BHTC became a founding member of the Council of Heads for Caribbean Schools, and a member of the International Consortium of Hotel and Tourism Institutes. Dahl-Brown fostered continual industry and academic upgrading of faculty while maintaining active direction of industry executives (Dahl-Brown, personal communication, 2014).

While there were several changes made to the program name, the BHTC maintained the offerings of three degree programs along with relevant certificate programs. Programs included the Ordinary Diploma in General Catering Skills, Ordinary Diploma in Hotel Management and Apprentice-Cook Certificate program certified by the American Culinary Federation (ACF). Certificate courses included Culinary Skills, Housekeeping Skills, Bookkeeping and Front Office Skills, Bakery Skills and Wine and Spirits Skills (Culmer, personal communication, 2014). The mission was altered in the mid-1990s as the industry changed its emphasis from that of old-time servitude to requiring employees to be efficient and courteous. The mission statement was to "develop human resources for national and international tourism, hospitality and allied industries by providing quality, vocational and technical training through applied academic education".

New programs were developed to include the
Applied Associate Degree in Hospitality Operations, the Applied Associate Degree in Culinary Arts, and the Apprentice Chef Associate Degree Program (Johnson, personal communication, 2014).

The student population began to outgrow the College Avenue facility so that in a quest for additional space the administration eventually secured a new campus, the Bahamas Tourism Training Center on Thompson Boulevard, funded by The World Bank. The Bahamas Tourism Training Center was opened in 1993 by Queen Elizabeth II as a shared complex with the BHTC and other major tourism and hospitality training entities such as The Ministry of Tourism's Bahamahost Program and the University of the West Indies Center for Hotel and Tourism Management (Johnson, personal communication, 2014).

In 1999, in a wish to advance national tertiary level education in the country, the Government of The Bahamas established a steering committee to review the viability of an amalgamation of the BHTC with the College of The Bahamas (COB). The recommended strategy of the steering committee was a 36-month transitional period to evaluate any challenges and to give both organizations sufficient time to unionize. Nevertheless, within nine months the staff and students of the BHTC were required to transfer offices and become students of the School of Hospitality and Tourism Studies of the COB (Johnson, personal communication, 2014). BHTC alumni expressed concern that, "the spirit of the institution lingers and the institution's value has been retained as much as possible" (Foulkes, personal communication, 2014). Research findings indicate that more than 5,000 persons received some form of related training from the BHTC. Students from 30 different countries were enrolled mostly from the Caribbean (University Transition Secretariat, 2013). The last foreign student entered the halls of the 
school in 2000.

The school has faced many challenges since the amalgamation including: loss of international accreditation, lowered student enrollment, reduced staff complement and morale, as well as cessation of financial contributions of the industry stakeholders (University Transition Secretariat, 2013, p. 84-85). Many of the faculty and alumni of the College who were interviewed are of the opinion that the COB was not committed to applied hospitality and tourism education. Olivia Saunders (2000-2001) was appointed Acting Dean of the School of Hospitality and Tourism Studies (SHTS) to lead the process of the amalgamation. She recommended converting the quarter system courses to match the semester courses offered by COB. The tourism curriculum from the School of Social Sciences was transferred to SHTS, and a bachelor degree program in hospitality was developed. Her tenure was short, only one year, and Peter Daniels (2001-2005) took over the helm of BHTC. In an interview Daniels said that there was a considerable amount of supervisory and staff dissatisfaction that sometimes bordered on alienation within the organization (Daniels, personal communication, 2014).

The SHTS has now expanded offerings to include two bachelor degree programs, three associate degree programs, and several certificate offerings. Tutors were reclassified as instructors and lecturers based on their academic qualifications. Despite the many challenges faced, SHTS recognized the need for greater autonomy to achieve its mission while maintaining academic integrity, hence the birth of the Culinary and Hospitality Management Institute (CHMI) in 2005. Its first Executive Director was former industry trainer Lincoln Marshall (2006-2009). Under his tenure Marshall restructured the school and formed partnerships with several colleges and universities, including the Barbados
Community College and the University of Guyana. Industry relations had been challenged since the amalgamation and Marshall sought to regain industry involvement (Johnson, personal communication, 2014). Increased student interest in hospitality and tourism programs was now comparable to the level of student interest in business programs. Enrollment began to increase.

Remelda Moxey (2009-2012) assumed the leadership as acting Executive Director. The level of dissatisfaction of faculty and staff was compounded by the dismantling of the industry-training department, which eventually led to the discontinuation of industry financial support. Coupled with the closure of the Freeport campus, much of the enduring value created by Marshall to rebrand and reclaim the Institute's prominence in tourism and hospitality training was placed on hold.

It had become evident that there was a need for strong management of CHMI with tourism and hospitality experience. Serving as Acting Executive Director, Kendal Johnson (20122013) quickly re-engaged the industry to provide new direction for the Institute. The first academic conference was held under Johnson's leadership and co-chaired by Donna Williams and Sophia Rolle. This conference partnered with two eminent tourism and hospitality universities: Cornell University's School of Hotel Administration and the Department of Hotel, Restaurant \& Institutional Management of the Lerner College of Business and Economics of the University of Delaware (Conference programme:

http://www.cob.edu.bs/conferences/chmiconfe rence2013.php). Johnson retired and his position was filled by Sophia Rolle (2013present). Under her leadership the Industry Training Department has been re-instituted, program offerings are being expanded and new policies are being developed. An 
aggressive marketing strategy has increased student enrollment in CHMI. The Institute is poised to expand its curriculum offerings, increase its professional development programs; provide online certificate courses along with its classroom-based programs.

\section{REFERENCES}

Bahamas Hotel Training College. (1997). The Bahamas Hotel Training College catalog. Nassau Bahamas: Author.

Smith, O. H. M., \& Glover, G. (1983). The practical realities of implementing change on a nationwide basis: The Bahamas Hotel Training Council, a case study. College Forum, 4, 32-38. http://dx.doi.org/10.15362/ijbs.v4i0.92

University Transition Secretariat. (2013). Draft final report. Nassau, Bahamas: The College of The Bahamas. Retrieved from http://www.cob.edu.bs/Council/uts/UTS_Fi nalReport_2013-10.pdf

\section{BIBLIOGRAPHY}

Rolle, S. (1996). Learning styles of postsecondary vocational education students and hotel managers in The Bahamas. College Forum, 6, 13-26. http://dx.doi.org/10.15362/ijbs.v8i0.22

Cleare, A. B. (2007). History of tourism in The Bahamas: A global perspective. S.l.: Xlibris.

\section{Interviews}

Blundell, S. (2014, March). The Bahamas Hotel Training College. (S. T., Interviewer)

Culmer, L. (2014, March). The Bahamas Hotel Training College. (S. T., Interviewer)

Dahl-Brown, I. (2014, March). The Bahamas Hotel Training College. (S. T., Interviewer)

Daniels, P. (2014, April 1). The School of Hospitality and Tourism Studies. (S. T., Interviewer)

Foulkes, B. (2014, February). The Bahamas Hotel Training College. (S. T., Interviewer)

Johnson, E. (2014, October). The Bahamas Hotel Training College. (D. Williams, Interviewer)

Johnson, K. (2014, March). The Bahamas Hotel Training College. (S. T., Interviewer)

Roker, L. C. (2014, March). The Bahamas Hotel Training College. (S. T., Interviewer)

Smith, M. (2014, March). The Bahamas Hotel Training College. (S. T., Interviewer) 